\title{
KEMAMPUAN KOMUNIKASI DAN DISPOSISI MATEMATIS MAHASISWA PADA MATA KULIAH GEOMETRI
}

\author{
Nola Nari \\ Program Studi Tadris Matematika STAIN Batusangkar. \\ Korespondensi:Jl.Sudirman No. 137 Kuburajo Lima Kaum Batusangkar. \\ e-mail: nolanari84@gmail.com
}

\begin{abstract}
This research was motivated by a fact that some of students of mathematics study program at STAIN Batusangkar have low ability in mathematics communication and mathematics disposition on Geometry subject. This is indicated by the students' inability to answer the questions on mathematics communication. In order to solve this problem, the researcher designed a research on learning strategy using Problem-based in Geometry subject. This research applied experimental method using randomized control group only design. The population of this research was the third semester students registered in 2014/2015 academic year. They consisted of three classes. The data were taken from the final test of each sample. The research findings show that the two hypotheses were accepted. Therefore, students' ability was better in mathematics communication by applying learning strategy using problem-based than conventional learning. In addition to this, students' ability was better in mathematics disposition by using learning strategy using problem-based than conventional learning.
\end{abstract}

Kata kunci: Kemampuan komunikasi, disposisi matematis, dan strategi pembelajaran berbasis masalah.

\section{PENDAHULUAN}

I lmu pengetahuan dan teknologi yang tiap tahun berkembang pesat menuntut setiap pelaku didalamnya untuk terus menerus memperbarui ilmu sehingga tercipta perubahan yang berdaya saing. Salah satu pelaku yang ikut andil dalam perkembangan IPTEK tersebut adalah para praktisi khususnya di bidang pendidikan. Matematika sebagai salah satu ilmu yang merupakan bagian penting dalam dunia pendidikan memunculkan perannya dalam hampir setiap unsur kehidupan. Matematika merupakan mata pelajaran wajib yang diajarkan di setiap jenjeng pendidikan mulai dari sekolah dasar hingga sekolah menengah atas sehingga dibutuhkan banyak tenaga pendidik di bidang tersebut.

Untuk menjawab tantangan akan kebutuhan tenaga pendidik matematika tersebut maka pihak perguruan tinggi hendaknya dapat menciptakan dan menghasilkan tenaga calon pengajar yang berkualitas, terampil, dan memiliki komunikasi yang bagus. Menurut Cokroft dalam Mulyono (1998: 253) menyatakan matematika perlu diajarkan karena matematika merupakan sarana komunikasi yang kuat, singkat dan jelas. Untuk memenuhi tuntutan tersebut maka dilakukan usaha secara berkesinam- 
bungan dengan mempersiapkan kurikulum tingkat perguruan tinggi yang selalu up to date dengan perkembangan zaman termasuk dengan kurikulum 2013 yang baru dikeluarkan dan sudah berjalan selama satu tahun.

Menurut kurikulum 2013 dalam Kementrian Pendidikan dan Kebudayaan dalam buku guru kelas X (2013: 10) pembelajaran matematika yang diharapkan dalam praktek pembelajaran adalah (1) pembelajaran berpusat pada aktivitas peserta didik, (2) peserta didik diberi kebebasan berpikir memahami masalah, membangun strategi penyelesaian masalah, mengajukan ide-ide secara bebas dan terbuka, (3) guru membimbing dan melatih peserta didik berfikir kritis dan kreatif dalam menyelesaikan masalah, (4) upaya guru mengorganisasikan, bekerja sama dalam kelompok belajar, melatih peserta didik berkomunikasi menggunakan grafik, diagram, skema dan variabel, (5) seluruh hasil kerja selalu dipresentasikan di depan kelas untuk menemukan berbagai konsep, hasil penyelesaian masalah, aturan matematika yang ditemukan melalui proses pembelajaran.

Sebagai bagian dari kurikulum 2013 yang menekankan pentingnya keseimbangan kompetensi sikap, pengetahuan dan keterampilan, kemampuan matematika yang dituntut dibentuk melalui pembelajaran berkelanjutan: dimulai dengan meningkatkan pengetahuan tentang metode-metode matematika, dilanjutkan dengan keterampilan menyajikan suatu permasalahan secara matematis dan menyelesaikannya, dan bermuara pada pembentukan sikap jujur, kritis dan kreatif, teliti dan taat aturan. Kesemuanya membutuhkan keterampilan dalam mengkolaborasi dan mengintegrasikan berbagai sumber yang ada sehingga tercipta pembelajaran yang baik.

Menurut Ali Hamzah (2014: 286) sistem matematika ada 5 bidang (sistem) yaitu teori bilangan (aritmatika), aljabar, geometri (yang membicarakan tentang sudut, garis, bidang dan ruang) dan analisis serta dasar matematika. Kurikulum 2013 melalui standar isinya telah mensyaratkan bahwa untuk tingkat perguruan tinggi mata kuliah pada program studi matematika salah satunya yaitu Geometri. Geometri merupakan materi dasar yang harus dikuasai mahasiswa karena baik secara eksplisit dan implisit materi geometri digunakan dalam kehidupan sehari-hari mahasiswa dalam menghadapi berbagai masalah. Kemampuan untuk menghadapi permasalahanpermasalahan, baik dalam permasalahan matematika maupun permasalahan dalam kehidupan nyata merupakan kemampuan daya matematis (mathematical power). Oleh karena itu bagaimana pembelajaran Geometri dilaksanakan sehingga dapat menumbuh kembangkan daya matematis mahasiswa.

Istilah "daya matematis" tidak tercantum secara eksplisit dalam kurikulum pembelajaran matematika di Indonesia, namun tujuan pembelajaran matematika dalam kurikulum di Indonesia (Depdiknas, 2006: 5) menyiratkan dengan jelas tujuan yang ingin dicapai yaitu: (1) Kemampuan pemecahan masalah (problem solving); (2) Kemampuan berargumentasi(reasonning); (3) Kemampuan berkomunikasi (communication); (4) Kemampuan membuat koneksi (connection) dan (5) Kemampuan representasi (representation). Kelima hal tersebut oleh NCTM (1999) dikenal dengan istilah standar proses daya matematis (Mathematical Power Proses Standards).

Matematika sebagai suatu mata pelajaran memiliki karakteristik tersendiri khususnya dalam bidang bahasa. Matematika merupakan bahasa yang memiliki kesamaan dengan bahasa lainnya. Menurut Elliott dan Kenny, 1996 (dalam Utari Sumarmo (2013: 2), dalam matematika terdapat "aturan sinus, aturan 
Pythagoras dan juga terdapat istilah ekspresi untuk menyatakan bentuk $3+4 x$ serta istilah kalimat untuk bentuk $x=2$ dan bentuk $3+4 x$ dan lain sebagainya". Seperti dalam bahasa lainnya dalam matematika juga terdapat symbol serta kata dan istilah yang dipinjam dari bahasa lain seperti ellips, parabola, hyperbola yang diambil dari bahasa Yunani. Bahasa-bahasa yang ada dalam matematika tersebut secara khusus juga terangkum dalam bidang Geometri yang menuntut kemampuan dari penggunanya untuk dapat mengkomunikasikan sebuah informasi dengan baik.

Ketika sebuah konsep informasi matematika diberikan oleh seorang pendidik kepada mahasiswa dan mereka juga mendapatkannya melalui bacaan, maka saat itu sedang terjadi transformasi informasi matematika dari komunikator kepada komunikan. Respon yang diberikan komunikan merupakan interpretasi komunikan tentang informasi tadi. Dalam matematika, kualitas interpretasi dan respon itu seringkali menjadi masalah istimewa. Hal ini sebagai salah satu akibat dari karakteristik matematika itu sendiri yang sarat dengan istilah dan simbol. Karena itu, kemampuan berkomunikasi dalam matematika menjadi tuntutan khusus yang harus dikuasai mahasiswa.

Menurut Greenes dan Schulman (dalam Utari Sumarmo (2013), komunikasi matematika memiliki peran: (1) kekuatan sentral bagi peserta didik dalam merumuskan konsep dan strategi matematika; (2) modal keberhasilan bagi peserta didik terhadap pendekatan dan penyelesaian dalam eksplorasi dan investigasi matematika; (3) wadah bagi peserta didik dalam berkomunikasi dengan temannya untuk memperoleh informasi, membagi pikiran dan penemuan, curah pendapat, menilai dan mempertajam ide untuk meyakinkan yang lain. Kemampuan berkomunikasi menjadi salah satu syarat yang memegang peranan penting karena membantu dalam proses penyusunan pikiran, menghubungkan gagasan dengan gagasan lain sehingga dapat mengisi hal-hal yang kurang dalam seluruh jaringan gagasan mahasiswa.

Selain kemampuan komunikasi yang harus dimiliki mahasiswa, disposisi matematis merupakan kemampuan yang esensial untuk dikembangkan maha siswa. Pentingnya pemilikan kemampuan komunikasi matematis dan disposisi matematis di atas termuat dalam tujuan Kurikulum Tingkat Satuan Pendidikan (KTSP, 2006): peserta didik memiliki kemampuan memahami konsep matematika dan kemampuan mengkomunikasikan gagasan atau idea matematika dengan menggunakan simbol, tabel, diagram, atau media lain, serta memiliki sikap positip (diposisi) terhadap kegunaan matematika dalam kehidupan, misalnya rasa ingin tahu, perhatian, dan minat mempelajari matematika, serta sikap ulet dan percaya diri dalam pemecahan masalah. KTSP 2006 menganjurkan agar pembelajaran matematika dimulai dengan pengenalan masalah yang sesuai dengan situasi (contextual problem), kemudian secara bertahap mahasiswa dibimbing secara komprehensif.

Dalam pelaksanaan dilapangan, perkuliahan geometri pada mahasiswa angkatan 2012 STAIN Batusangkar sudah menggunakan berbagai macam pendekatan dan strategi. Mereka sudah mampu memahami konsep matematika dan tidak lagi dengan sistem hafalan. Berdasarkan hasil penelitian yang dilakukan oleh Nola Nari (2013: 60) tentang analisis kemampuan pemecahan masalah matematis mahasiswa tadris matematika pada mata kuliah geometri transformasi menunjukkan bahwa pada 
aspek komunikasi matematis yang ada dalam indikator pemecahan masalah matematis belum menunjukkan hasil maksimal. Hal ini terlihat pada indikator 3 dan 4 dalam pemecahan masalah matematis tentang ketepatan urutan langkah dan kebenaran tulisan untuk menjelaskan langkah belum menunjukkan hasil yang memuaskan pada setiap kelompok analisis.

Dalam perkuliahan geometri analitik bidang dan ruang terlihat juga bahwa peserta didik cendrung tidak mau memberikan penjelasan secara tertulis tentang pemecahan masalah yang telah mereka lakukan. Mereka sering menggunakan cara cepat dalam menyelesaikan persoalan geometris dengan mengabaikan defenisi-defenisi dan dalil yang terkait dengan persoalan yang sudah mereka ketahui sebelumnya pada mata kuliah geometri bidang dan ruang. Secara umum, tujuan perkuliahan geometri bidang dan ruang adalah peserta mampu mengidentifikasi dan menerapkan sifat-sifat bidang dan bangun ruang.

Berdasarkan observasi dilapangan pada pertemuan perdana mata kuliah geometri bidang dan ruang tahun pelajaran 2014/2015 diperoleh informasi bahwa mahasiswa banyak yang enggan dan tidak mampu menjawab secara lisan dan tertulis tentang beberapa prinsip dan defenisi dasar yang ada pada geometri. Misalnya saat ditanya tentang pengertian titik dilihat dari berbagai bangun berdimensi (garis, bidang, ruang maupun titik sebagai unsur tunggal). Hal ini disebabkan karena mahasiswa tidak mampu menghubungkan benda nyata, gambar dan diagram kedalam ide matematika sehingga berakibat pada ketidakmampuan mahasiswa menjelaskan baik secara lisan dan tulisan. Hal ini termasuk salah satu dari indikator kemampuan komunikasi matematis yang harus dikuasai oleh mahasiswa calon pendidik sebagai bekal mereka dilapangan.
Untuk mengatasi masalah tersebut dibutuhkan suatu strategi yang sesuai dan cocok dalam pembelajaran. Oleh sebab itu, hendaklah pendidik memberikan kebebasan untuk menggunakan pengetahuan dan keterampilan intelektualnya sehingga tercapai domain kognitif yang menunjukkan tujuan pendidikan yang terarah kepada kemampuan komunikasi dan sikap dalam menghargai matematika yang ditunjukkan dengan disposisi matematis yang baik.

Untuk meningkatkan komunikasi dan disposisi matematis perlu diterapkan strategi pembelajaran yang sesuai. Strategi pembelajaran yang dirasa cocok salah satunya adalah dengan mencoba menerapkan strategi pembelajaran berbasis masalah. Pembelajaran berbasis masalah menurut Ali Hamzah (2014: 165) adalah suatu strategi pembelajaran yang diawali dengan penyajian masalah yang dirancang dalam konteks yang relevan dengan materi yang dipelajari. PBM melibatkan peserta didik dalam penyelidikan pilihan sendiri yang memungkinkan mereka menginterpretasikan dan menjelaskan fenomena dunia nyata dan membangun pemahaman tentang fenomena tersebut.

\section{METODE PENELITIAN}

Metode yang digunakan dalam penelitian ini adalah metode eksperimen dengan dua kelompok. Kelompok eksperimen menerapkan pembelajaran berbasis masalah sedangkan kelompok kontrol melakukan pembelajaran konvensional. Variabel dalam penelitian ini terdiri atas dua variabel yaitu variabel bebas dan variabel terikat. Sebagai variabel bebas yaitu pembelajaran berbasis masalah, sedangkan variabel terikatnya adalah hasil belajar peserta didik, yaitu kemampuan komunikasi dan disposisi matematis dalam pemecahan masalah. Penelitian ini dilaksanakan 
pada semester Ganjil 2014/2015 pada mata kuliah Geometri Bidang dan ruang.

Populasi penelitian ini adalah mahasiswa yang mengambil mata kuliah Geometri Bidang dan Ruang yang terdiri dari tiga kelas TMTK-A, TMTK-B dan TMTK-C setara. Dalam penelitian ini TMTK-A dan TMTK-B dipilih sebagai kelas eksperimen karena distribusi mahasiswa perbaikan cukup bervariasi dan sama-sama berjumlah 9 orang dibanding TMTK-C yang mahasiswanya murni adalah mahasiswa angkatan 2013.

Dalam penelitian ini digunakan dua instrumen yaitu, (1) tes hasil belajar kemampuan komunikasi matematis (Geometri). Pemberian tes akhir (tes hasil belajar) untuk melihat kemampuan komunikasi matematis mahasiswa dalam memecahkan masalah setelah mendapat perlakuan pembelajaran berbasis masalah dan pembelajaran konvensional. Dalam penyusunan tes hasil belajar kemampuan komunikasi matematis, diawali dengan penyusunan kisi-kisi soal berdasarkan indicator komunikasi matematis yaitu: (1) Kemampuan menghubungkan benda nyata, gambar, dan diagram ke dalam ide matematika; (2) Kemampuan menjelaskan ide, situasi, dan relasi matematika secara tulisan; (3) Kemampuan menyatakan peristiwa atau ide dalam bahasa atau simbol matematika.Pembelajaran yang dilakukan mencakup sub pokok bahasan segi tiga, segi empat dan melukis, kemampuan yang diukur, indikator serta jumlah butir soal. Setelah membuat kisi-kisi soal, dilanjutkan dengan menyusun soal yang terdiri dari 2 butir soal dengan 7 sub pertanyaan untuk tiap butir soal dan aturan pemberian skor seperti pada tabel 1 di bawah. Sebelum digunakan dalam penelitian, soal tes hasil belajar kemampuan matematis divalidasi oleh pakar.

Table 1: Rubrik Penskoran Kemampuan Komunikasi Matematis

\begin{tabular}{|c|c|c|}
\hline Indikator & Respon Mahasiswa & Skor \\
\hline \multirow{5}{*}{$\begin{array}{l}\text { 1. Menghubungkan benda } \\
\text { nyata, gambar, dan } \\
\text { diagram ke dalam ide } \\
\text { matematika. }\end{array}$} & $\begin{array}{l}\text { a. Jawaban benar, mampu } \\
\text { menghubungkan benda nyata, gambar, } \\
\text { dan diagram ke dalam ide matematika. }\end{array}$ & 4 \\
\hline & $\begin{array}{l}\text { b. Jawaban benar, sesuai dengan kriteria } \\
\text { tetapi ada sedikit jawaban yang salah }\end{array}$ & 3 \\
\hline & $\begin{array}{l}\text { b. Jawaban benar tetapi tidak sesuai } \\
\text { dengan sebagian besar criteria }\end{array}$ & 2 \\
\hline & $\begin{array}{l}\text { d. Jawaban ada tetapi sama sekali tidak } \\
\text { sesuai dengan criteria }\end{array}$ & 1 \\
\hline & e. Jawaban tidak ada & 0 \\
\hline \multirow[t]{5}{*}{$\begin{array}{l}\text { 2. Menjelaskan ide, situasi } \\
\text { dan relasi matematik } \\
\text { secara tulisan. }\end{array}$} & $\begin{array}{l}\text { a. Jawaban benar, mampu menjelakan ide, } \\
\text { situasi dan relasi matematik secara } \\
\text { tulisan }\end{array}$ & 4 \\
\hline & $\begin{array}{l}\text { b. Jawaban benar, sesuai dengan kriteria } \\
\text { tetapi ada sedikit jawaban yang salah }\end{array}$ & 3 \\
\hline & $\begin{array}{l}\text { c. Jawaban benar tetapi tidak sesuai } \\
\text { dengan sebagian besar criteria }\end{array}$ & 2 \\
\hline & $\begin{array}{l}\text { d. Jawaban ada tetapi sama sekali tidak } \\
\text { sesuai dengan criteria }\end{array}$ & 1 \\
\hline & e. Jawaban tidak ada & 0 \\
\hline $\begin{array}{l}\text { 3. Menyatakan peristiwa } \\
\text { atau ide dalam bahasa }\end{array}$ & $\begin{array}{l}\text { a. Jawaban benar, mampu menyatakan } \\
\text { peristiwa sehari-hari dalam bahasa atau }\end{array}$ & 4 \\
\hline
\end{tabular}




\begin{tabular}{llc}
\hline atau simbol matematika. & \multicolumn{3}{l}{ simbol matematika. } & \\
\cline { 2 - 3 } & b. Jawaban benar, sesuai dengan kriteria & 3 \\
& tetapi ada sedikit jawaban yang salah & \\
\hline $\begin{array}{l}\text { c. Jawaban benar tetapi tidak sesuai } \\
\text { dengan sebagian besar criteria }\end{array}$ & 2 \\
\hline $\begin{array}{ll}\text { d. Jawaban ada tetapi sama sekali tidak } \\
\text { sesuai dengan kriteria }\end{array}$ & 1 \\
\hline e. Jawaban tidak ada & 0 \\
\hline $\begin{array}{l}\text { d. Jawaban ada tetapi sama sekali tidak } \\
\text { sesuai dengan criteria }\end{array}$ & 1 \\
\hline & S. Jawaban tidak ada & 12 \\
\hline
\end{tabular}

Intrumen ke dua yang digunakan adalah angket disposisi matematis (Geometri). Angket kemampuan disposisi matematis digunakan untuk mengungkap secara umum kemampuan disposisi matematis (Geometri) mahasiswa terhadap pembelajaran berbasis masalah. Model angket yang digunakan adalah model sakala Likert. Angket ini diberikan kepada mahasiswa kelompok eksperimen setelah mereka melakukan tes akhir. Jawaban angket dalam penelitian ini seperti yang dikemukakan oleh Ruseffendi (2001: 120) yaitu SS (Sering Sekali), S (Sering), Kd (Kadang-kadang), Jr (Jarang), dan Js (Jarang sekali). Sebelum butir-butir angket dirumuskan terlebih dahulu disusun kisi-kisi angket yang mengacu kepada indicator disposisi matematis yaitu: (1). Kepercayaan diri dalam menyelesaikan masalah matematika (Geometri), mengkomunikasikan ide-ide, dan memberi alasan. (2). Fleksibilitas dalam mengeksplorasi ide-ide matematis (Geometri) dan mencoba berbagai metode alternatif untuk memecahkan masalah. (3). Bertekad kuat untuk menyelesaikan tugas-tugas matematika (Geometri). (4). Ketertarikan, keingintahuan, dan kemampuan untuk menemukan dalam mengerjakan mate- matika (Geometri); (5). Kecenderungan untuk memonitor dan merefleksi proses berpikir dan kinerja diri sendiri. (6). Menilai aplikasi matematika (Geometri) dalam bidang lain dan dalam kehidupan sehari-hari. (7). Penghargaan (appreciation) peran matematika (Geometri) dalam budaya dan nilainya, baik matematika sebagai alat, maupun matematika sebagai bahasa. Berdasarkan kisikisi angket tersebut maka disusun angket disposisi matematis. Sebelum dilakukan penyebaran angket kepada mahasiswa dilakukan validasi angket oleh pakar.

Dalam pengumpulan data ini ditentukan sumber data, kemudian jenis data, teknik pengumpulan, dan instrumen yang digunakan berupa soal tes dan angket disposisi matematis. Setelah data didapat maka dilakukan uji perbandingan rata-rata untuk ke dua kelas penelitian untuk melihat pengaruh penggunaan strategi pada kedua kelas penelitian.

\section{HASIL DAN PEMBAHASAN}

Hasil dari penelitian yang diperoleh dari tes kemampuan komunikasi matematis terdapat pada tabel 2 berikut: 
Tabel 2: Nilai Frekuensi Statistik Kemampuan Komunikasi

\begin{tabular}{lcc}
\hline & Eksperimen & Kontrol \\
\hline $\mathrm{N} \quad$ Valid & 36 & 39 \\
\hline Mean & 57.5236 & 49.4669 \\
\hline Median & 54.1700 & 41.6700 \\
\hline Mode & 75.00 & 41.67 \\
\hline Std. Deviation & 20.81697 & 18.21645 \\
\hline Variance & 433.346 & 331.839 \\
\hline Range & 75.00 & 66.67 \\
\hline Minimum & 25.00 & 25.00 \\
\hline Maximum & 100.00 & 91.67 \\
\hline Sum & 2070.85 & 1929.21 \\
\hline
\end{tabular}

Dari tabel 2 diatas yang diolah dengan software SPSS 18 diperoleh nilai rata-rata kedua kelas penelitian terdapat perbadaan dengan nilai kelas eksperimen lebih baik disbanding nilai pada kelas kontrol.
Setelah dilaksanakan tes kemampuan komunikasi matematis mahasiswa mengisi angket disposisi matematis pada kedua kelas sampel, diperoleh data tentang hasil angket disposisi matematis mahasiswa seperti tabel 3 berikut:

Tabel 3: Nilai Frekuensi Statistik angket Disposisi Matematis

\begin{tabular}{lll}
\hline & \multicolumn{1}{c}{ Eksperimen } & \multicolumn{1}{c}{ Kontrol } \\
\hline $\mathrm{N} \quad$ Valid & 34 & 39 \\
\cline { 2 - 3 } \multicolumn{1}{c}{ Missing } & 2 & 0 \\
\hline Mean & 106.35 & 107.28 \\
\hline Median & 106.00 & 109.00 \\
\hline Mode & 106 & 112 \\
\hline Std. Deviation & 6.134 & 10.151 \\
\hline Variance & 37.629 & 103.050 \\
\hline Range & 24 & 40 \\
\hline Minimum & 93 & 83 \\
\hline Maximum & 117 & 123 \\
\hline Sum & 3616 & 4184 \\
\hline
\end{tabular}

Berdasarkan table 3 di atas diketahui pengisian angket disposisi matematis mahasiswa diikuti oleh 75 orang mahasiswa, yang terdiri atas 34 mahasiswa kelas eksperimen (dengan 2 mahasiswa tidak melengkapi pengisian angket sehingga dinyatakan sebagai data yang gagal) dan 39 mahasiswa kelas kontrol.

\section{Analisis Hasil Tes Kemampuan Komunikasi Matematis Mahasiswa}

a. Uji Normalitas

Hasil uji normalitas kedua kelas penelitian dapat dilihat pada Tabel 4 . 
Tabel 4. Uji Normalitas Kelas Eksperimen dan Kelas Kontrol

\begin{tabular}{cccccc}
\hline Kelas & $\alpha$ & $n$ & $L_{0}$ & $L_{\text {tabel }}$ & Distribusi \\
\hline Eksperimen & 0,05 & 36 & 0,10584 & 0,1889 & Normal \\
\hline Kontrol & 0,05 & 39 & 0,0823 & 0,1889 & Normal \\
\hline
\end{tabular}

Berdasarkan Tabel 4 terlihat bahwa $L_{0}$ kedua kelas sampel lebih rendah dari $L_{\text {tabel }}$. Hal ini menunjukkan bahwa kedua kelas sampel berdistribusi normal. b. Uji Homogenitas

Setelah dilakukan uji normalitas, langkah selanjutnya adalah melakukan uji homogenitas. Hasil uji homogenitas dapat dilihat pada tabel 5berikut:

Tabel 5. Hasil Uji Homogenitas Kelas Eksperimen dan kelas Kontrol

\begin{tabular}{lccccc}
\hline \multicolumn{1}{c}{ Kelas } & $n$ & $f_{\frac{\alpha}{2}}\left(v_{1}, v_{2}\right)$ & $f_{1-\frac{\alpha}{2}}\left(v_{1}, v_{2}\right)$ & $f$ & $\begin{array}{c}\text { Keteranga } \\
\mathbf{n}\end{array}$ \\
\cline { 1 - 5 } Eksperimen & 36 & 2,1 & 0,47619 & $\begin{array}{c}0,701 \\
75\end{array}$ & Homogen \\
\hline Kontrol & 39 & 2,1 & & & \\
\hline
\end{tabular}

Dari Tabel 5 terlihat bahwa $f_{1-\frac{\alpha}{2}}\left(v_{1}, v_{2}\right)<f<f_{\frac{\alpha}{2}}\left(v_{1}, v_{2}\right) \quad$ Atau $0,47619<f<2,1$ dengan $f=$ 0,70175. Hal ini menunjukkan bahwakedua kelas sampel memiliki variansi yang homogen.

\section{c. Uji Hipotesis}

Sampel berdistribusi normal dan memiliki variansi yang homogen maka dilanjutkan dengan uji hipotesis dengan cara menggunakan uji-t. hasilnya dapat dilihat pada tabel 6 .

Tabel 6. Hasil Uji Hipotesis Hasil Tes Kemampuan Komunikasi Matematis Siswa

\begin{tabular}{cccccc}
\hline Kelas & $n$ & $\bar{x}$ & $s$ & $\boldsymbol{T}$ & $\boldsymbol{t}_{\boldsymbol{\alpha}}$ \\
\hline Eksperimen & 36 & 57,5236 & 20,81 & & \multirow{2}{*}{4,799} \\
\hline Kontrol & 39 & 49,4669 & 18,21 & &
\end{tabular}

Berdasarkan Tabel 6 diperoleh rensial dengan menggunakan data hasil $\mathrm{t}=4,799$ dan $\mathrm{t}$ alfa 1,645 sehingga $t>t_{\alpha} \quad$ transformasi data ordinal angket. Dalam dan terdapat perbedaan kemampuan analisis statistik terlebih dahulu dilakukomunikasi di antara kedua kelas penelitian dengan penerapan strategi pembelajaran berbasis masalah di kelas eksperimen dan pembelajaran konvensional di kelas kontrol.

\section{Analisis Hasil Angket Disposisi Matematis Mahasiswa}

Untuk menarik kesimpulan tentang data yang diperoleh dari hasil tes angket disposisi matematis mahasiswa, dilakukan analisis data secara statistik infe- kan uji normalitas dan uji homogenitas pada kedua kelas sampel.

a. Uji Normalitas

Uji normalitas dilakukan dengan caraUji Liliefors. Uji ini dilakukan pada kedua kelas sampel yaitu kelas eksperimen dan kelas kontrol. Dan mengenai hasil uji tersebut dapat dilihat pada Tabel 7. 
Tabel 7. Uji Normalitas Kelas Eksperimen dan Kelas Kontrol

\begin{tabular}{cccccc}
\hline Kelas & $\alpha$ & $n$ & $L_{0}$ & $L_{\text {tabel }}$ & Distribusi \\
\hline Eksperimen & 0,05 & 34 & 0,10584 & 0,1889 & Normal \\
\hline Kontrol & 0,05 & 39 & 0,0823 & 0,1889 & Normal \\
\hline
\end{tabular}

Berdasarkan Tabel 7 terlihat bahwa $L_{0}$ kedua kelas sampel lebih rendah dari $L_{\text {tabel. }}$. Hal ini menunjukkan bahwa kedua kelas sampel berdistribusi normal. b. Uji Homogenitas

Setelah dilakukan uji normalitas, langkah selanjutnya adalah melakukan uji homogenitas. Hasil uji homogenitas dapat dilihat pada tabel 8.

Tabel 8. Hasil Uji Homogenitas Kelas Eksperimen dan kelas Kontrol

\begin{tabular}{cccccc}
\hline \multicolumn{1}{c}{ Kelas } & $n$ & $f_{\frac{\alpha}{2}}\left(v_{1}, v_{2}\right)$ & $f_{1-\frac{\alpha}{2}}\left(v_{1}, v_{2}\right)$ & $f$ & $\begin{array}{c}\text { Keteranga } \\
\mathbf{n}\end{array}$ \\
\cline { 1 - 3 } Eksperimen & 34 & 2,1 & 0,47619 & $\begin{array}{c}0,7017 \\
5\end{array}$ & Homogen \\
\hline Kontrol & 39 & & &
\end{tabular}

Dari Tabel 8 terlihat bahwa $f_{1-\frac{\alpha}{2}}\left(v_{1}, v_{2}\right)<f<f_{\frac{\alpha}{2}}\left(v_{1}, v_{2}\right) \quad$ Atau $0,47619<f<2,1$ dengan $f=$ 0,70175. Hal ini menunjukkan bahwakedua kelas sampel memiliki variansi yang homogen. c. Uji Hipotesis

Sampel berdistribusi normal dan memiliki variansi yang homogen maka dilanjutkan dengan uji hipotesis dengan cara menggunakan uji-t. hasilnya dapat dilihat pada tabel 9 .

\section{Tabel 9. Hasil Uji Hipotesis Angket Disposisi Mahasiswa}

\begin{tabular}{cccccc}
\hline Kelas & $n$ & $\bar{x}$ & $s$ & $\boldsymbol{T}$ & $\boldsymbol{t}_{\boldsymbol{\alpha}}$ \\
\cline { 1 - 4 } Eksperimen & 34 & 50,0047 & 10,00044 & \multirow{2}{*}{2,065} & \multirow{2}{*}{1,645} \\
\cline { 1 - 4 } Kontrol & 39 & 50,0020 & 10,00035 & & \\
\hline
\end{tabular}

Berdasarkan Tabel 9 diperoleh nilai $\mathrm{t}$ sebesar 2,065 dan $\mathrm{t}$ alfa sebesar 1,645 hal ini menunjukkan $t>t_{\alpha}$ dan terdapat perbedaan disposisi matematis diantara kedua kelas dengan penerapan strategi pembelajaran berbasis masalah di kelas eksperimen dan pembelajaran konvensional dikelas kontrol.

\section{Pembahasan}

1. Strategi pembelajaran berbasis masalahdan tes kemampuan komunikasi matematis mahasiswa

Penelitian ini dilakukan untuk mengetahui apakah kemampan ko- munikasi matematis mahasiswa dengan penerapan Strategi pembelajaran berbasis masalah lebih baik dari kemampuan komunikasi matematis siswa dengan penerapan metode pembelajaran konvensional. Berdasarkan hasil pengolahan di atas diperoleh analisis data yaitu uji normalitas tes kemampuan komunikasi matematis menunjukkan bahwa sampel berasal dari populasi yang berdistribusi normal. Pengujian selanjutnya dilakukan dengan uji homogenitas variansi yang menunjukkan bahwa tidak terdapat perbedaan antara kelas eksperimen 
dan kelas kontrol, artinya kedua kelas memiliki variansi yang homogen. Kemudian uji perbedaan dua rata-rata data tes kemampuan komunikasi matematis dilakukan dengan menggunakan uji t. Dari hasil analisis uji t dengan $\alpha=0,05$ mendapatkan thitung $=$ 4,7999 dan $t_{\text {tabel }}=1,671$, hal ini menunjukkan bahwa nilai thitung lebih besar dari tabel. Berdasarkan kriteria pengujian hipotesis $\mathrm{H}_{0}$ ditolak, ini berarti bahwa kemampuan komunikasi matematis mahasiswa dengan penerapan strategi pembelajaran berbasis masalah lebih baik dari kemampuan komunikasi matematis mahasiswa dengan penerapan metode pembelajaran konvensional pada materi bangun datar segi tiga, segi empat dan melukis bangun menggunakan jangkar dan penggaris.

Dari analisis hasil tes per indikator untuk kemampuan komunikasi. Pada indikator 1 skor maksimalnya dari semua soal adalah 8 . Untuk kelas eksperimen rata-rata yang diperoleh untuk indikator pertama yaitu 5,69, sedangkan pada kelas kontrol rata-rata yang diperoleh yaitu 5,05. Dari perbedaan rata-rata tersebut terlihat bahwa kelas eksperimen lebih unggul dalam kemampuan komunikasi untuk indikator 1 yaitu tentang menyatakan gambar, diagram, bahasa, symbol, ekspresi atau model matematika kedalam bahasa sendiri.

Pada indikator 2 skor maksimalnya dari semua soal adalah 8 . Untuk kelas eksperimen rata-rata yang diperoleh untuk indikator kedua yaitu 4,388, sedangkan pada kelas kontrol rata-rata yang diperoleh yaitu 3,79. Dari perbedaan rata-rata tersebut terlihat bahwa kelas eksperimen lebih unggul dalam kemampuan komunikasi untuk indikator 2 yaitu tentang menyatakan suatu situasi ke dalam bentuk gambar, diagram, ba- hasa, symbol, ekspresi atau model matematika.

Pada indikator 3 skor maksimalnya dari semua soal adalah 8 . Untuk kelas eksperimen rata-rata yang diperoleh untuk indikator ketiga yaitu 3,72, sedangkan pada kelas kontrol rata-rata yang diperoleh yaitu 3,02 . Dari perbedaan rata-rata tersebut terlihat bahwa kelas eksperimen lebih unggul dalam kemampuan komunikasi untuk indikator 2 yaitu tentang menggunakan istilah-istilah, notasi-notasi metematika dan struktur-strukturnya untuk menyajikan ide, menggambarkan hubungan-hubungan dan model-model situasi.

Ketiga indikator kemampuan komunikasi tersebut merupakan indikator kemampuan komunikasi tertulis. Berdasarkan analisis indikator tersebut terlihat bahwa terdapat perbedaan kemampuan komunikasi matematis mahasiswa pada kedua kelas penelitian. Berdasarkan pengamatan peneliti selama penelitian, proses pembelajaran dengan Strategi pembelajaran berbasis masalah cukup mampu meningkatkan kemampuan komunikasi matematis mahasiswa.

Pada setiap pertemuan terlebih dahulu peneliti menginformasikan mengenai tujuan pembelajaran kepada mahasiswa dan materi pelajaran yang akan diberikan. Selanjutnya peneliti memberikan apersepsi dan motivasi kepada mahasiswa tentang pentingnya memahami materi bangun datar segitiga, segiempat dan melukis bangun yang merupakan materi utama yang akan terpakai saat mereka menjadi seorang guru kelak. Materi ini merupakan materi dasar yang sangat terkait erat dengan keseharian mahasiswa sebagai individu maupun dalam lingkungan. Kemudian peneliti menjelaskan proses yang akan dilakukan dengan menggunakan strategi pembelajaran berbasis masalah 
dan menjelaskan hal apa saja yang harus dikerjakan mahasiswa. Setelah peneliti memberikan materi kepada mahasiswa dengan mengorientasikan mahasiswa pada masalah, mahasiswa diminta untuk mengorganisir masalah sehingga mampu melakukan komunikasi yang baik dari masalah matematis tersebut. KBK (Depdiknas, 2006: 11) juga menyatakan bahwa kemampuan matematika yang dipilih serta ditetapkan sudah dirancang sesuai dengan kemampuan dan kebutuhan peserta didik agar dapat berkembang secara optimal, maka kompetensi yang berkait dengan komunikasi ini harus dicapai selama proses pembelajaran sedang berlangsung di kelas.

Dalam pembelajaran dengan strategi berbasis masalah setiap masalah yang diberikan adalah masalah kontekstual dan open ended sehingga mudah untuk diamati, dianalisis dan dikomunikasikan oleh mahasiswa. Masalah-masalah kontekstual dan open ended yang dimunculkan dalam perkuliahan mampu memancing mahasiswa berdiskusi dalam kelompok kecil sehingga membuat mahasiswa dilatih untuk berkomunikasi. Proses ini diawali dengan mengasah kemampuan mahasiswa untuk menafsirkan masalah kontekstual dan open ended menjadi bahasa matematis berupa memberikan lambang atau simbol matematis. Hal ini sesuai dengan NCTM, (1996) berpendapat, "Jika kita sepakat bahwa matematika itu merupakan suatu bahasa dan bahasa tersebut sebagai bahasan terbaik dalam komunitasnya, maka mudah dipahami bahwa komunikasi merupakan esensi dari mengajar, belajar, dan meng-assess matematika".

2. Kemampuan Disposisi Matematis

Setelah tes kemampuan komunikasi matematik diberikan kepada mahasiswa maka dilanjutkan dengan pemberian angket disposisi matematis pada kelas eksperimen dan kelas control. Angket disposisi matematis berisi sejumlah pertanyaan yang menunjukkan sikap individu mahasiswa terhadap geometri dan kebiasaanya dalam menghadapi permasalahan matematika khususnya geometri.

Berdasarkan hasil pengolahan di atas diperoleh analisis data yaitu uji normalitas tes kemampuan komunikasi matematis menunjukkan bahwa sampel berasal dari populasi yang berdistribusi normal. Pengujian selanjutnya dilakukan dengan uji homogenitas variansi yang menunjukkan bahwa tidak terdapat perbedaan antara kelas eksperimen dan kelas kontrol, artinya kedua kelas memiliki variansi yang homogen. Kemudian uji perbedaan dua rata-rata data tes kemampuan komunikasi matematis dilakukan dengan menggunakan uji t. Dari hasil analisis uji t dengan $\alpha=0,05$ mendapatkan $t_{\text {hitung }}=$ 2,065 dan $t_{\text {tabel }}=1,645$ hal ini menunjukkan bahwa nilai thitung lebih besar dari tabel. Berdasarkan kriteria pengujian hipotesis $\mathrm{H}_{0}$ ditolak, ini berarti bahwa kemampuan disposisi matematis mahasiswa dengan penerapan strategi pembelajaran berbasis masalah lebih baik dari kemampuan disposisi matematis mahasiswa dengan penerapan metode pembelajaran konvensional pada materi bangun datar segi tiga, segi empat dan melukis bangun menggunakan jangkar dan penggaris.

Selain dari hasil analisis dan uji-t, perbedaan kemampuan disposisi matematis mahasiswa pada kedua kelas penelitian juga bisa diamati selama proses perkuliahan berlangsung. Kelas TMTK III B yang pembelajarannya menggunakan strategi pembelajaran berbasis masalah terlihat lebih aktif dan gigih dalam me- 
nyelesaikan masalah. Mulyana (2009:19) disposisi terhadap matematika adalah perubahan kecendrungan peserta didik dalam memandang dan bersikap terhadap matematika, serta bertindak ketika belajar matematika.

Strategi pembelajaran berbasis masalah yang dibarengi dengan diskusi kelompok kecil mampu membuat mahasiswa merasa percaya diri dalam menyelesaikan masalah matematika(geometri). Mereka merasa lebih lel-uasa dan berani mengkominikasikan idenya kepada teman kelompok atau-pun antar kelompok untuk mem-berikan alternative solusi jawaban dari permasalahan kontekstual dan open ended yang diberikan.

Dalam perkuliahan pada materi bangun datar segi empat, mahasiswa dibagi dalam 6 kelompok yang terdiri 5 sampai 6 mahasiswa. Setiap kelompok diberikan nama persegi, persegi panjang, jajargenjang, trapezium, belah ketupat dan layinglayang. Setiap anggota kelompok diminta membuat bangun datar yang bervariasi menggunakan selembar kertas sesuai nama kelompok masingmasing. Misalkan pada kelompok trapezium, setiap anggota kelompok membuat trapezium berbeda seperti: trapezium siku-siku, trapezium sama kaki, trapezium sembarang, dll. Berdasarkan bangun yang mereka miliki selanjutnya diminta untuk menuliskan cirri-ciri yang dimiliki bangun tersebut, selanjutnya mereka mendiskusikan cirri-ciri tersebut dengan anggota kelompok yang sama untuk membuat generalisasi dari cirri-ciri yang ditemukan. Diskusi ini dilanjutkan dengan debat antar kelompok untuk menemukan kesamaan dan perbedaan antara kelima bangun datar segi empat tsb. Perkuliahan yang terjadi cukup menarik dimana antar kelompok mahasiswa saling beradu argument, misalnya saat kelompok belah ketupat mengemukakan cirri bangunnya diantaranya yaitu sudut yang berhadapan sama besar dan diagonalnya berpotongan sama panjang. Ciri ini juga dimiliki oleh kelompok persegi tetapi lebih spesifik.

Dari diskusi yang berlangsung terlihat sekali mahasiswa cukup fleksibel dalam mengeksplorasi ideide matematis berdasarkan bangun yang telah mereka hasilkan. Mereka mencoba berbagai metode alternatif untuk memecahkan masalah. Mereka merasa mempunyai rasa ingin tahu yang tinggi karena materi yang dimunculkan sangat kontekstual dan open ended dan nyata bagi mahasiswa.

\section{PENUTUP}

\section{Kesimpulan}

Berdasarkan hasil penelitian yang dilaksanakan di kelas TMTK b, TMTK a mahasiswa tadris maatematika angkatan 2013 dan setelah dilakukan uji t terhadap hipotesis yang diajukan dalam penelitian ini, yaitu: "Kemampuan komunikasi matematis siswa dengan penerapan Strategi pembelajaran berbasis masalah lebih baik dibandingkan dengan kemampuan komunikasi matematis dengan penerapan metode pembelajaran konvensional dan Kemampuan disposisi matematis siswa dengan penerapan Strategi pembelajaran berbasis masalah lebih baik dibandingkan dengan kemampuan disposisi matematis dengan penerapan metode pembelajaran konvensional pada mahasiswa tadris matematika semester III STAIN Batusangkar".

\section{Saran}

Berdasarakan hasil penelitian, peneliti mengemukakan beberapa saran, antara lain: 
1. Bagi Mahasiswa Tadris matematika

a. Kemampuan komunikasi adalah hal yang terpenting untuk dikembangkan oleh mahasiswa calon pendidik matematika

b. Kemampuan disposisi matematis merupakan sikap positif yang harus selalu dibina dan dikembang-

\section{DAFTAR RUJUKAN}

Ali Hamzah,Drs,M.Pd,Dkk. (2014). Perencanaan dan Strategi Pembelajaran Matematika. Jakarta. Raja Gafindo Persada.

Depdiknas-Pusat Kurikulum - Balitbang (2002). Kurikulum Berbasis Kompetensi Mata Pelajaran Matematika. Jakarta.

Depdiknas (2006). Kurikulum Tingkat Satuan Pendidikan SMA. Tersedia online pada http://www.puskur.co.id, Juli 2011.

Hamzah Opu, Problem Posing dan Problem Solving dalam Pembelajaran Mateematika, (Bandung: PustakaRamadhan, 2003).

Kementrian Pendidikan dan Kebudayaan, Dokumen Kurikulum 2013, (Online).

Tersedia:http://aziseko77.files.wor dpress.com/2013/11/dokumenkurikulum-2013.pdf. (Diakses tanggal 5 Januari 2014).

Mulyono Abdurrahman (1998). Pendidikan bagi Anak berkesulitan Belajar. Jakarta. kan oleh setiap mahasiswa tadris matematika

c. Strategi pembelajaran berbasis masalah merupakan salah satu alternative untuk meningkatkan kualitas pembelajaran mahasiswa.

2. Bagi STAIN Batusangkar

NCTM. (1996). Curriculum and Evaluation Standards for School Mathematics. Reston, VA: NCTM

Nola Nari, (2013). Analisis Kemampuan Komunikasi Matematis Mahasiswa Tadris Matematika Pada mata Kuliah Geometri Transformasi. Laporan Penelitian. Tidak diterbitkan.

Ruseffendi, ET 1991. Pengantar Kepada Membantu Guru Mengembangkan Kompetensinya dalam Pengajaran Matematika untuk Meningkatkan CBSA. Bandung : Tarsito.

Utari, S. (2013) Berpikir dan Disposisi Matematik serta Pembelajarannya. Jurusan Pendidikan Matematika FMIPA UPI. Bandung.

Utari Sumarmo, Januari 2010- Hal: 26 Wardani, S. (2009) Meningkatkan emampuan berfikir kreatif dan disposisi matematik peserta didik SMA melalui pembelajaran dengan pendekatan model Sylver. . Diakses pada tanggal 27 Mei 2011 pada ttp://www.matedu.cinvestav.mx/ad alira.pdf 